\title{
A CIDADE, O POEMA, A NAÇÃO
}

\author{
WANDER MELO MIRANDA
}

UFMG

Dos vários retratos de Mário de Andrade que Pedro Nava passa em revista em Beira-mar, um dos mais sugestivos é criação do próprio memorialista. Numa noite de 1924 , sozinho na sacada do Grande Hotel de Belo Horizonte, o ilustre visitante paulista transfigura-se "numa espécie de enorme concha eletrônica", munida de óculos que "pareciam holofotes varrendo a noite" da cidade. O que aí a lembrança ressalta, e o inusitado da expressão reforça, é a capacidade incomum de Mário de "captar o canto gigantesco do Brasil", cujos acordes se farão ouvir no poema-síntese da viagem da caravana modernista a Minas - o "Noturno de Belo Horizonte".

Escrito no mesmo ano da visita à cidade, o 
"Noturno" a ela retorna em 1939 pela voz do seu autor. Como registram os jornais da época, Mário declama o poema após uma das duas conferências que faz na capital mineira, a convite do Diretório Central dos Estudantes. Sua nova estada em Belo Horizonte, a terceira, reveste-se, diz a Folha de Minas, "da feição de verdadeiro acontecimento literário", em virtude da relevância do escritor no cenário nacional $\mathrm{e}$, de maneira muito particular, pelo que ele vinha representando para diferentes gerações de intelectuais mineiros. Testemunhar a continuidade dessa presença em 1993, quando são comemorados os cem anos de nascimento de Mário, é refazer seu percurso pela cidade, recolher de outra perspectiva as impressões então gravadas em letra e som - viagens do poeta.

A opção do viajante pelo marco urbano, enquanto espaço privilegiado da indagação e do conhecimento, traduz-se em termos de uma reverberação acústica luminosa, signo de fundação da cidade-poema: "Maravilha de milhares de brilhos vidrilhos". Em contraposição à cidade funcional, traçada na prancheta com rigor geométrico, a cidade cubofuturista do poeta fragmenta-se, multifacetada e polifônica, em percepções simultâneas, heterogêneas, às vezes contraditórias. Anula, assim, por meio da letra sinuosa do poema, a cidade então planejada para satisfazer o desejo de racionalidade modernizante que conseguira ultrapassar as montanhas de Minas.

\section{Belo Horizonte desapareceu Transfigurada nas recordações.}

Porque matéria da reminiscência, a cidade apresenta-se como possibilidade de fábula, de fantasia, abrindo brechas no âmbito da idealização histórica que, em nome da utopia do progresso, recalca o embate de forças entre civilização e barbárie. Sob a forma de instantâneos fotográficos que vão se acumulando em ritmo acelerado no poema, a delimitação de fronteiras espaciais e temporais é revertida e deslocada em prol de uma configuração constelar. No lusco-fusco da noite, turno propício à imaginação e à melancolia - numa palavra, ao "desvairismo" —, o brilho das estrelas, seu "estardalhaço de luzes", superpõe-se à iluminação artificial, tornando descontínua a linearidade geométrica imposta à topografia natural e liberando das sombras (da cidade, da história) "o artifício e o defeito".

Que luta pavorosa entre floresta e casas...

Todas as idades humanas

Macaqueadas por arquiteturas históricas

Torres torreões torrinhas e tolices

Brigam em nome da?

Os mineiros secundam em coro:

- Em nome da civilização!

Minas progride.

Também quer ter também capital moder níssima também...

Nada no projeto executado na construção da nova capital remete às antigas cidades mineiras, cujas soluções arquitetônicas e urbanísticas resultam da tradição -- mestiça, diria Mário lentamente amadurecida no decorrer do período colonial. Ao contrário, a transposição mimética de modelos europeus faz tábula rasa da referida tradição e, bem de acordo com o espírito positivista da virada do século, pauta-se pelo mito do novo como esteio do progresso e norma civilizatória ordenadora do país a que a República viera dar forma. $\mathrm{O}$ anseio de modernização assim postulado é objeto da mirada irônica do poeta que descortina o primarismo dos resultados obtidos ("torres... tolices") e a repetição compulsiva que a eles subjaz ("também... também") e se reflete, em larga escala, na atabalhoada adaptação da burguesia local às exigências e modas da urbe moderna.

Ao efeito de "despaisamento" - para usar termo empregado por Mário em carta a Drummond -, o poeta reage mediante o rompimento do tecido urbano, situando-se de través, oblíquo, em relação à perspectiva por este imposta, inaugurando, em conseqüência, ângulos de visão imprevistos, outros horizontes. O noturno, fora dos trilhos, corre solto pela ci- 
dade, como o mato, avança sobre ela, desloca seus marcos territoriais e temporais. $\mathrm{O}$ noturno vira rio: "E o estouro dos rios começou".

$\mathrm{O}$ artificial e o construído cedem à força da natureza, excluída da ordem dos signos urbanos; a impostação letrada que os enforma abre espaço para o resgate da oralidade das culturas rurais ou populares, em processo de desintegração. A operação, poética por excelência, se realiza através da mixagem de vozes distintas, a do viajante citadino e a do contador anônimo, ambos perfazendo a figura do narrador que se atualiza na lenda da serra do Rola-Moça e no caso do coronel Antônio de Oliveira Leitão. Histórias simples, de amores contrariados pela fatalidade da morte, pela "Fortuna inviolável": uma construída intencionalmente sob a forma de "uma moda popular, em redondilha", con "metrificação ingênua, balbuciante primitiva, lírica", como diz o poeta mais uma vez a Drummond; a outra, comentário em prosa, conversa proseada.

Mas não há nada como histórias pra reunir na mesma casa...

Na Arábia por saber contar histórias Ua mulher se salvou...

Nas mil e uma noites do "Noturno", uma tradição é retomada, estendida em "língua do ão" além dos limites do traçado retórico do mapa da incipiente metrópole. De norte a sul, as ruas levam nome de tribos indígenas, poetas inconfidentes, personagens históricos; de leste a oeste são homenageados os estados brasileiros, as cidades mineiras -- "uma verdadeira aula de história e geografia do Brasil", segundo L.J. Magalhães Gomes. Vazia, acrescente-se, ideologicamente interessada na pretensão de integrar o território nacional e os fatos históricos sob a égide da nova norma urbana, a toponimia original da cidade será desarticulada no poema, tornada habitável pelo povoamento -- arlequinal -_ dos signos-ruas desertos.

Vem, gente! vem ver o noturno de Belo Horizonte!
O convite procura reunir na cidade, casa aberta tornada imensa praça pública, "multidões matizadas" de brasileiros de todos os quadrantes do país, "mésalliances" (tão combatidas pelo coronel Leitão...) em que até fantasmas da história se corporificam e entram na dança. $O$ poema, espaço da diferença, "desgeografiza" assim o mapa urbano concebido como uma totalidade sem fraturas e, ao fazê-lo, propõe formas disjuntivas de representação da nacionalidade, marcadas pela diversidade cultural e étnica e contrárias à normatividade homogênea, racionalizante. Mais uma mudança de tom, agora pela voz do poeta travestido de orador. Diz Mário, a respeito da sua atitude: "o mais diletante e envenenado dos meus amigos, Rubens de Morais me disse que eu ainda acabava escrevendo letras de hino nacional. Minha resposta foi que se carecesse escreveria. E sob esse ponto eu grito que tenho uma saúde mental formidável, que pode vir duma ilusão, pouco me importa! Me faz imensamente feliz".

Entre dicção oratória e marcação da diferença, o poeta-viajante abre caminho para chegar enfim ao nome da cidade: belo horizonte de perspectivas fincadas no presente, eco da lembrança de felicidade que só a tessitura carnavalizada do poema alcança recuperar, desentranhando da história o bloco do "Custa mas vai", em ritmo fremente de "celebração do Universal". O desenho de uma nação brasileira adquire aqui contornos que descartam a oposição excludente entre nacional e universal, cuja rigidez irá comprometer, até o limite do regionalismo ou do fascismo, parte do projeto modernista então em curso. Como Mário esclarece em 1924 a Drummond, a aludida oposição inexiste quando se pensa o ser nacional como portador de traços distintivos que são universais justamente por serem diferenciais, isto é, por contribuírem para incrementar a polifonia das civilizaçōes _- "o dia em que nós formos inteiramente brasileiros e só brasileiros a humanidade estará rica de mais uma raça, rica duma nova combinação de qualidades humanas. As raças são acordes musicais". No que pese hoje certo exagero da proposição 
100 ANOS DE MÁRIO

("e só brasileiros"...), sua estratégia alerta, como observou Silviano Santiago em artigo sobre "elogio da tolerância étnica", para o acerto maior de Mário, ao negar a visão etnocêntrica de uma civilização única, cuja hegemonia só se dá pela violência sobre as demais.

A coda do "Noturno" encarna a dinâmica musical - das etnias e das culturas. A cidade desprende-se do traço frio da prancheta e toma corpo, agora já habitável. Respira, enfim aliviada, o ar da noite provinciana, pronta para receber a serenata do cantor ambulante - concha e holofote.

...os poros abertos da cidade

Aspiram com sensualidade com delícia

$O$ ar da terra elevada.

Ar arejado batido nas pedras dos morros,

Varado através da água trançada das cachoeiras,

Ar que brota nas fontes com as águas

Por toda a parte de Minas Gerais.

\section{RÉSUMÉ}

Lecture de "Noturno de Belo Horizonte", de Mário de Andrade à partir de la configuration du paysage urbaine en tant qu'espace d'une sorte de savoir et d'une image de nation. 